\title{
PRODUKTIVITAS RUMPUT Panicum maximum CV. GREEN PANIC PADA BERBAGAI TARAF PEMUPUKAN KOTORAN SAPI DALAM KONDISI TERNAUNG DAN TANPA NAUNGAN
}

\author{
I Wayan Wirawan, I Wayan Suarna, Ni Nyoman Suryani, Anak Agung, \\ Ayu Sri Trisnadewi, dan Ni Luh Gede Sumardani \\ Puslitbang Tumbuhan Pakan Universitas Udayana, Denpasar, Bali \\ e-mail: wirawanfapet@yahoo.co.id; puslitbangtp@gmail.com
}

\begin{abstract}
ABSTRAK
Penelitian ini bertujuan untuk mengetahui pengaruh pemupukan kotoran sapi terhadap produktivitas rumput Panicum maximun Cv. Green Panic dalam kondisi ternaung dan tanpa Penelitian menggunakan rancangan acak kelompok pola split-plot 2 x 4 dengan 3 ulangan. Petak utama adalah naungan dan tanpa naungan. Anak petak adalah pupuk kotoran sapi $\left(0,10,20\right.$, dan $\left.30 \mathrm{t} \mathrm{ha}^{-1}\right)$. Variabel yang diamati dalam penelitian ini adalah tinggi tanaman, jumlah daun, jumlah anakan, diameter batang, berat kering akar, produksi hijauan dan produksi inflorescense. Hasil penelitian menunjukkan bahwa tidak terjadi interaksi antara naungan dan dosis pupuk kotoran sapi terhadap produktivitas rumput Panicum maximun Cv. Green Panic. Pemberian naungan sebesar 70 \% menurunkan produksi hijauan, jumlah anakan, diameter batang, berat kering akar dan produksi inflorescense rumput panikum $(\mathrm{P}<0,05)$. Peningkatan pemberian pupuk kotoran sapi meningkatkan semua peubah yang diamati tetapi belum menunjukkan respons yang nyata.
\end{abstract}

Kata kunci: naungan, pupuk kotoran sapi, produksi hijauan, dan Panicum maximum

\section{PRODUCTIVITY OF Panicum maximum CV. GREEN PANIK UNDER VARIOUS LEVELS OF CATTLE MANURE FERTILIZER UNDER SHADE AND WITHOUT SHADE CONDITIONS}

\begin{abstract}
The research was carried out to study the effect of cattle manure fertilizer on produktivity of Panicum maximun Cv. Green Panic under shade and without shade conditions. The research used a block randomized design with split plot treatment arrangement and 3 replications. The main plot was shade and withaout shade and the sub plots were 4 level of cattle manure fertilizer $\left(0,10,20\right.$, dan $\left.30 \mathrm{t} \mathrm{ha}^{-1}\right)$. The parameter of this research is grass height, number of leave, number of tillers, diameter of steam, dry wight of roots, forage and inflorescense production. The results of research showed that not interaction between shade and level cattle manure fertilizer on productivity Panicum maximun Cv. Green Panic. The use of shade $70 \%$ decreasing of forage productions, number of tiller, diameter of steam, dry weight of roots and inflorescense production panicum grass $(\mathrm{P}<0,05)$. Increasing the use of cattle manur fertilizer increased of all parameter but not significantly.
\end{abstract}

Key words: shade, cattle manur fertilizer, forage production, and Panicum maximum.

\section{PENDAHULUAN}

Dalam usaha peternakan khususnya ternak ruminansia, tersedianya hijauan pakan ternak yang cukup sepanjang tahun baik dari segi kualiats maupun kuantitas merupakan salah satu faktor penting yang perlu diperhatikan untuk menjaga kelangsungan produksi. Hijauan merupakan sumber sumber pakan utama bagi ternak ruminasia, sehingga ketersediaanya secara kualitas dan kuantitas sepanjang tahun mutlak diperlukan (Sukarji et al., 2006).

Petani peternak khususnya di daerah Bali sangat kesulitan dalam mengembangkan penanaman hijauan pakan ternak, hal ini disebabkan karena terbatasnya lahan untuk mengembangkan hijauan pakan secara khusus. Lahan-lahan yang lebih produktif digunakan untuk penanaman tanaman pangan. Di lain pihak, banyak lahan-lahan ternaung seperti di bawah pohon perkebunan dapat dikembangkan untuk menanam hijauan pakan. Lahan-lahan dibawah pohon perkebunan seperti perkebunan kelapa terbatas akan faktor-faktor tumbuh seperti hara, air, dan cahaya matahari (Rika, 1994).

Untuk mengatasi hal tersebut, evaluasi tentang 
tumbuhan yang tahan terhadap naungan mutlak diperlukan. Salah satu rumput hasil evaluasi tersebut adalah Panicum maximum. Panicum maximun terdapat beberapa varietas yaitu type raksasa $(C v$. Hamil dan Coloniao); type sedang (Cv. Common, Gatton, Makueni); dan type pendek ( $\mathrm{Cv}$ Sabi dan Petri). Rumput Panicum maximum Cv Green Panic merupakan salah satu varietas dari rumput Panicum maximum Cv Petri ( Petri Green panik / Panicum maximum $\mathrm{Cv}$. Trichoglume) yang berbatang banyak, berdaun lebat dan pendek, tinggi tanaman mencapai $1 \mathrm{~m}$, dan tahan terhadap naungan (Reksohadiprojo, 1985). AAK (2012) menyatakan bahwa Panicum maximum termasuk tanaman berumput berumur panjang, tumbuh tegak, mempunyai rumpun yang banyak, akar seraabut dalam, tahan kekeringan dan produksinyan mencapai 150 ton/Ha. Krisnajaya (1989) menyatakan bahawa produksi rumput Panicum (Panicum maximum $\mathrm{Cv}$. Riverdale) masih dapat dipertahankan dengan baik sampai pada naungan $25 \%$, sedangkan pada naungan $50 \%$ produksinya menurun.

Kendala lain pada pengembangan rumput di bawah perkebunan adalah terbatasnya unsur hara pada tanah. Pemupukan merupakan salah satu cara untuk meningkatkan kandungan hara dalam tanah. Pemupukan bertujuan untuk memelihara dan memperbaiki kesuburan tanah dengan memberikan unsur hara ke dalam tanah (Suriatna, 1992). Salah satu pupuk yang dapat digunakan adalah pupuk kotoran sapi. Pemakaian pupuk kotoran sapi selain memanfaatkan limbah peternakan, pupuk kotoran sapi banyak mengandung mikroorganisme pengurai yang bermanfaat untuk meningkatkan unsur hara dan miroorganisme. Pupuk kotoran sapi mengandung

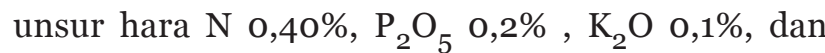
$\mathrm{H}_{2} \mathrm{O} 92 \%$ (Setyamidjaja, 1986). Wahyuningsih (2004) menyatakan bahwa penggunaan pupuk kotoran sapi pada dosis 20 ton/Ha dapat meningkatkan produktivitas leguminosa Pueraria phaseoloides var Javanica yang maksimal.

Informasi tentang produktivitas rumput Panicum maximum Cv. Green Panic dalam kondisi ternaung dan tanpa ternaung dengan pemupukan kotoran sapi masih jarang didapatkan, oleh karena itu penelitian ini perlu dilakukan untuk mendapatkan level pupuk kotoran sapi yang optimal dalam kondisi ternaung dan tanpa naungan.

\section{MATERI DAN METODE}

\section{Bibit Rumput}

Bibit rumput yang digunakan dalam penelitian ini adalah Panicum maximun $C v$. Green Panik yang diperoleh dari kebun STS Fapet UNUD Bukit
Jimbaran.. Bibit dalam bentuk serpihan rumpun dan di potong dengan panjang $20 \mathrm{~cm}$.

\section{Tanah}

Tanah yang digunakan sebagai media tumbuh tanaman diperoleh dari daerah Jalan Tukad Balian, Renon, Denpasar. Tekstur tanah lempung dengan kandungan N-Total o,1\% (sangat rendah); C-Organik 1,81\% (rendah); P tersedia 104,01 ppm (sangat tinggi); $\mathrm{K}$ tersedia 78,2 ppm (rendah); dan pH 7,3 (netral). Tanah sebelum digunakan terlebih dahulu dikeringkan udarakan kemudian diayak dengan ayakan berukuran $2 \times 2 \mathrm{~mm}$.

\section{Pupuk}

Pupuk yang digunakan adalah pupuk kotoran sapi dengan kandungan N-Total 0,79\% (sangat tinggi); C-Organik 17,27\% (sangat tinggi); P tersedia 554,49 ppm (sangat tinggi); K tersedia 777,00 ppm (sangat tinggi); dan $\mathrm{pH} \mathrm{6,4} \mathrm{(agak} \mathrm{masam).} \mathrm{Pupuk} \mathrm{kotoran}$ kandang diberikan pada saat penanaman deng taraf yaitu $\mathrm{O}, 10,20,30$ ton/Ha.

\section{Penaung}

Penaung yang digunakan adalah plastik strimin (shade cloth) dengan tingkat naungan 70\%. Intensitas naungan diukur dengan alat Light Meter Digital $L X$ 103.

\section{Rancangan Percobaan}

Percobaan ini menggunakan Rancangan Acak Kelompok dengan pola Split Plot 2 x 4 dengan 3 ulangan. Petak utama adalah naungan dan tanpa naungan. Anak petak adalah pemupukan kotoran sapi dengan 4 level pemupukan yaitu o, 10, 20, 30 ton/Ha

Pengambilan dan Analisis Data

Pemotongan dilakukan pada saat umur tanaman 8 minggu. Variabel yang diamati adalah produksi hijauan dan produksi inflorenses. Data yang diperoleh dianalisis dengan analisis sidik ragam dan apabila perlakuan menunjukkan perbedaan yang nyata $(\mathrm{P}<0,05)$ maka dilanjutkan dengan uji jarak berganda dari Duncan (Steel dan Torrie, 1991).

\section{HASIL DAN PEMBAHASAN}

Hasil penelitian menujukkan bahwa tidak terjadi interaksi antara perlakuan naungan dan level pupuk kotoran sapi terhadap produktivitas rumput Panicum maximun Cv. Green Panic. Pada Tabel 1 menunjukkan bahwa penanaman rumput Panicum maximun $\mathrm{Cv}$. Green Panic dalam kondisi ternaung $70 \%$ mengalami penurunan yang nyata $(\mathrm{P}<0,005)$ terhadap jumlah anakan, diameter batang, berat kering akar, produksi hijauan dan inflorescense, 
sedangkan terhadap tinggi tanaman, dan jumlah daun tidak menunjukkan perbedaan yang nyata $(\mathrm{P}>0,05)$. Hal ini disebabkan oleh perbedaan intensitas radiasi sinar matahari yang diterima oleh tumbuhan pada perlakuan ternaung dan tanpa ternaung berbeda. Pada perlakuan yang ternaung dimana penaungnya cukup tinggi (70\%) menyebabkan laju fotosintesis pada tanaman mengalami penurunan sehingga karbohirat yang terbentuk juga sangat rendah. Dengan menurunnya metabolisme karbohirat maka produksi vegetatif tanaman seperti daun, batang, bunga dan akar juga akan mengalami penurunan. Harjadi (1979) menyatakan bahwa fase vegetatif tanaman terjadi pada perkembangan akar, daun dan batang sangat tergantung pada penyediaan karbohidrat yang cukup.

Pada variabel tinggi tanaman (Tabel 1), hasil penelitian menunjukkan bahwa terjadi peningkatan tinggi tanaman pada perlakuan ternaung tetapi secara statistik menunjukkan perbedaan yang tidak nyata $(\mathrm{P}>0,05)$. Hal ini disebabkan karena tanaman rumput Panicum maximum $\mathrm{C} v$. Green panic dalam kondisi ternaung akan berusaha untuk mendapatkan sinar matahari sehingga tanaman akan tumbuh memanjang dan kurus. Bidwell (1979) menyatakan bahwa pertumbuhan tanaman yang kekurangan sinar lebih cepat ke atas sehingga batangnya lebih panjang dan pertumbuhan ke sampingnya lambat, sedangkan tanaman yang cukup mendapat sinar pertumbuhan batangnya lebih pendek dan pertumbuhan ke sampingnya lebih cepat sehingga areal yang ditutupi lebih luas. Widiana (1995) menyatakan bahwa tidak terdapat interaksi yang nyata $(\mathrm{P}>0,05)$ antara naungan dengan dosis pupuk nitrogen terhadap pertumbuhan dan produksi rumput Stenotaphrum secundatum Cv. Vanuatu.

Tabel 1. Pengaruh Naungan dan Tanpa Naungan Terhadap Produktivitas Panicum maximum Cv. Green Panic

\begin{tabular}{lccc}
\hline \multirow{2}{*}{\multicolumn{1}{c}{ Variabel }} & \multicolumn{2}{c}{ Perlakuan ${ }^{1)}$} & \multirow{2}{*}{ SEM $^{3}$} \\
\cline { 2 - 3 } & $\mathrm{N}$ & $\mathrm{T}$ & \\
\hline Tinggi Tanaman (cm) & $\left.126,58 \mathrm{a}^{2}\right)$ & $125,21 \mathrm{a}$ & 1,08 \\
Jumlah Daun (helai) & $67,25 \mathrm{a}$ & $70,00 \mathrm{a}$ & 1,27 \\
Jumlah Anakan (batang) & $12,42 \mathrm{~b}$ & $20,92 \mathrm{a}$ & 0,37 \\
Diameter Batang (cm) & $0,20 \mathrm{~b}$ & $0,31 \mathrm{a}$ & 0,01 \\
Berat Kering Akar (g) & $1,18 \mathrm{~b}$ & $5,78 \mathrm{a}$ & 0,54 \\
Berat Kering inflorescense (g) & $0,27 \mathrm{a}$ & $2,27 \mathrm{a}$ & 0,05 \\
Produksi Berat Kering Hijauan (g) & $9,67 \mathrm{~b}$ & $18,96 \mathrm{a}$ & 1,06 \\
\hline
\end{tabular}

Keterangan:

1) N: Naungan

T: Tanpa Naungan

2) Nilai dengan huruf yang sama pada baris yang sama menunjukkan tidak berbeda nyata $(P>0,05)$

3) SEM: Standard Error of The Treatment Means

Dalam kondisi ternaung yang tinggi (70\%) tanaman rumput Panicum maximum Cv. Green Panic masih mampu tumbuh dan berproduksi meskipun mengalami penurunan produktivitas yang nyata
$(\mathrm{P}<\mathrm{O}, 05)$ dibandingkan dengan tanpa naungan. Hal ini disebabkan karena rumput ini merupakan salah satu cultivar dari Panicum maximum yang tahan terhadap naungan. Oleh sebab itu tanaman rumput ini masih dapat hidup dengan baik dalam kondisi yang ternaung. Reksohadiprodjo (1985) menyatakan bahwa rumput panicum dapat hidup dengan baik pada tempat yang ternaung karena dapat beradaptasi pada intensitas sinar yang bervariasi.

Pemberian perlakuan level perlakuan pemupukan yang bervariasi pada produktivitas rumput Panicum maximun $\mathrm{Cv}$ Green Panic cenderung mengalami peningkatan terhadap semua variabel yang diamati kecuali pada berat kering akar dan berat kering inflorescence tetapi secara statistik berbeda tidak nyata (Tabel 2). Hal ini disebabkan karena pemberian pupuk kotoran sapi pada penelitian ini belum mampu secara nyata memenuhi kebutuhan tanaman akan unsur hara terutama kebutuhan N. Nitrogen berfungsi untuk meningkatkan kadar protein dalam tanaman, penting dalam memproduksi biji dan pembuahan, disamping itu penting dalam pembentukan zat hijau daun, mampu merangsang pertumbuhan vegetatif tanaman (anakan, tunas, daun), dan meningkatkan kandungan protein tanaman (Whiteman, et al., 1980). Kaca (2006) melaporkan bahwa peningkatan penggunaan dosis nitrogen mampu meningkatkan pertumbuhan dan hasil hijauan pakan ternak.

Tabel 2. Pengaruh Taraf Pupuk Kotoran Sapi Terhadap Produktivitas Panicum maximum Cv. Green Panic

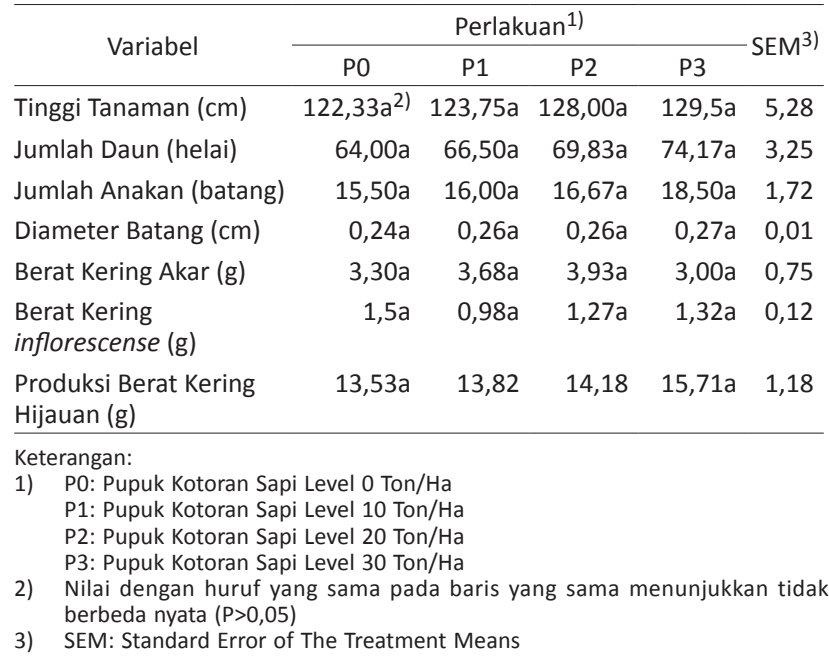

Hal lain yang diduga menyebabkan produktivitas rumput Panicum maximum $\mathrm{Cv}$ Green Panic yang dipupuk dengan pupuk kotoran sapi belum berpengaruh nyata $(\mathrm{P}<0,05)$ adalah disebabkan karena pupuk kotoran sapi merupakan pupuk yang responnya lambat sehingga tanaman masih kekurangan zat makanan (unsur hara) yang dibutuhkan untuk tumbuh dan berproduksi. Suteja (1999) menyatakan bahwa pupuk kotoran sapi merupakan pupuk dingin 
dan proses perubahannya berlangsung lambat dan kurang terbentuk panas. Lambatnya proses pelapukan disebabkan oleh sifat fisik pupuk padatnya yang banyak mengandung air dan lendir. Pupuk kotoran sapi apabila terkena udara menyebabkan pupuk berkerak sehingga proses oksidasi di dalam tumpukan pupuk berjalan lambat karena udara dan air sulit masuk ke dalamnya. Pupuk kotoran sapi untuk dapat diserap oleh tanaman harus melalui proses dekomposisi terlebih dahulu (Partoharjono et al., 1984)

Pengaruh level penggunaan pupuk kotoran sapi dalam penelitian ini secara umum cenderung mengalami peningkatan terhadap produksi hijauan tetapi secara statistik berbeda tidak nyata $(\mathrm{P}>0,05)$. Peningkatan penggunaan pupuk kotoran sapi menyebabkan bertambahnya unsur hara dalam tanah yang akan dimanfaatkan oleh tanaman untuk tumbuh dan berproduksi. Wibawa, et al. (2014) melaporkan bahwa penggunaan pupuk kotoran sapi memberikan respon yang nyata pertumbuhan, produksi, karakteristik produksi dan kualitas hijauan rumput gajah. Perlakuan dosis pupuk kandang 45 ton/ha menghasilkan produksi rumput gajah lebih tinggi dibandingkan dengan perlakuan 30, 15 ton/ ha dan tanpa pupuk kandang (Khaladin et al., 2013)

\section{SIMPULAN DAN SARAN}

\section{Simpulan}

Dari hasil penelitian ini dapat disimpulkan bahwa tidak terjadi interaksi antara perlakuan naungan dengan level pupuk kotoran sapi terhadap produktivitas rumput Panicum maximun $\mathrm{Cv}$. Green Panik. Produktivitas Panicum maximun Cv. Green Panik pada perlakuan naungan nyata lebih rendah $(\mathrm{P}<0,05)$ dibandingkan dengan tanpa naungan sedangkan produktivitas Panicum maximun $C v$. Green Panik pada perlakuan pupuk kotoran sapi 30 ton/ha mengalami peningkatan tetapi berbeda tidak nyata $(\mathrm{P}>0,05)$ dibandingkan tanpa pemupukan.

\section{Saran}

Perlu dilakukan penelitian lanjutan dengan menggunakan pupuk kotoran sapi dengan level yang lebih tinggi pada rumput Panicum maximun Cv. Green Panik pada kondisi ternaung .

\section{UCAPAN TERIMA KASIH}

Penulis mengucapkan terima kasih kepada Dekan Fakultas Peternakan Universitas Udayana, Ketua Puslitbang Tumbuhan Pakan Universitas Udayana yang telah memberikan fasilitas untuk mengadakan penelitian ini.

\section{DAFTAR PUSTAKA}

AAK. 2012. Hijauan Makanan Ternak Potong, Kerja dan Perah. Penerbit Kanisius, Yogyakarta.

Bidwell, R.G.S. 1979. Plant Physiology. Sec. Ed. Macmilan Publising Co. Inc. New York.

Harjadi, M.M.S.S. 1979. Pengantar Agronomi. P.T. Gramedia, Jakarta.

Kaca, I N. 2006. Pengaruh Dosis Nitrogen dan Beberapa Jenis Rumput Unggul Terhadap Pertumbuhan dan Hasil Hijauan Makanan Ternak. Tesis. Program Pasca Sarjana, Universitas Udayana, Denpasar.

Khaladin, I. Mirza, dan A. Aris. 2013. Aplikasi FMA dan Pupuk Kandang Terhadap Produksi dan Kualitas Rumput Gajah (Pennisetum purpureum Schum). Prosiding Semnas II HITPI, Denpasar.

Krisnajaya, A.A.N. 1989. Pengaruh Naungan Terhadap Produksi Rumput Panicum (Panicum maximum Cv. Riversdale). Skripsi, Fakultas Peternakan Universitas Udayana, Denpasar.

Partoharjono, S.M., Ismunadji, dan S.N. Darwis. 1984. Padi. Balai Penelitian Tanaman Pangan, Bogor.

Rika, I K., 1994. Integrasi Pakan Hijauan dan Ternak Ruminansia dengan Perkebunan Kelapa. Orasi Pengenalan Guru Besar Tetap dalam Bidang Tanaman Makanan Ternak pada Fakultas Peternakan Universitas Udayana, Denpasar.

Reksohadiprodjo, S. 1985. Produksi Tanaman Hijauan Makanan Ternak Tropis. Penerbit BPFE, Yogyakarta.

Setyawidjaya, D.M.E. 1986. Pupuk dan Pemupukan. Penerbit CV. Simplek, Jakarta.

Sukarji, N W., I W. Suarna, dan I B.G. Partama. 2006. Produktivitas Rumput Stenotaphrum secundatum Cv. Vanuatu Pada Berbagai Taraf Pemupukan Nitrogen Dalam Kondisi Ternaung dan Tanpa Ternaung. Majalah Ilmiah Peternakan, Penerbit Fakultas Peternakan Universitas Udayana, Denpasar.

Suriatna, S. 1992. Pupuk dan Pemupukan. Mediyatama Sarana Pustaka. Jakarta.

Suteja, M.M. 1999. Pupuk dan Pemupukan. Bineka Cipta, Jakarta.

Steel, R.G.D. dan R.A. Torrie. 1991. Prinsip dan Prosedur Statistika. Suatu Pendekatan Biomatrik. Gramedia Pustaka Utama, Jakarta.

Wahyuningsih, I. 2004. Produktivitas Pueraria phaseoloides Var. Javanica Dipupuk Dengan Dosis Pupuk Kandang Dari Sapi yang Diberi Ransum Berkonsentrat Disuplementasi Ammonium Sulfat. Skripsi, Fakultas Peternakan Universitas Udayana, Denpasar.

Whitemen, P.C., S.A. Waring, E.S. Wallis and R.C. Bruce. 1980. Tropical Pasture Science. Oxford University Press, Australia.

Wibawa, A.A.P.P., I G.B.A. Parwata, I W. Wirawan, N L.G. Sumardani dan I W. Suberata. 2014. Respons Rumput Gajah (Pennisetum purpureum Schumach) Terhadap Aplikasi Pupuk Urea, Kotoran Ayam, dan Kotoran Sapi Sebagai Sumber Nitrogen (N). Majalah Ilmiah Peternakan, Penerbit Fakultas Peternakan Universitas Udayana, Denpasar.

Widiana, I G.N.A. 1995. Pertumbuhan dan Produksi rumput Stenotaphrum secundatum Cv. Vanuatu Pada Berbagai Taraf Pemupukan Nitrogen Dalam Kondisi Ternaung dan Tanpa Naungan. Skripsi, Fakultas Peternakan Universitas Udayana, Denpasar. 